\title{
PROJECT METHOD IN TECHNOLOGY AND IT EDUCATION
}

\author{
Henryk Noga \\ Uniwersytet Pedagogiczny w Krakowie, Poland \\ Jana Depešová \\ Univerzita Konštantína Filozofa v Nitre, Slovakia
}

\begin{abstract}
Based on the research it can be stated that both primary and junior high school students and teachers have different views on the effectiveness of project method used on technology and IT classes. The vast majority of students were the most satisfied with the practical classes that effectively combined theoretical and practical tasks. This form of work to a great extent fostered students' activity. Unfortunately, although teachers were interested in using project method on technology and IT lessons, the way of using it can be questionable. Teachers emphasize the fact that not all issues can be achieved using this method.
\end{abstract}

Keywords: IT classes, junior high school, primary school, project method, teachers, technology education.

\section{Introduction}

In the time of educational reform traditional learning methods are increasingly being replaced by more efficient methods of educational dialogue. In a situation where the student has to master a vast and difficult material, practical methods such as project method, are gaining in importance. Effective learning and practical application of acquired knowledge makes students see that the effort they put into their education process brings them great benefit (Kajdasz-Aouil et al., 2005, Mastalerz, 2006, Petlák, 1997).

The aim of the research is to try to find answers to the question whether the project method in technology and IT classes bring the expected teaching effects.

\section{Application of selected methods of education in a technical education}

Technology because of its specific nature, makes students more than on any other classes undertake activities that enable them to develop creativity. The activity which accompanies them, makes it easier to acquire a simple content and experience they acquire progressively works later in a adulthood (Prauzner, Ptak, 2014, Pytel, 2011, Šimonová, 2006, Vargová, 2005).

Observing technology classes taught by experienced teachers show that the activating methods give much better results than traditional methods. 


\section{The use of selected teaching methods in IT education}

Today computer classes are not only science lessons. From an early age children begin to use computers with curiosity, keep track of the news and learn their secrets. Because of such wide application of computers, IT teacher faces a very difficult task. Historically, PCs were used only to mobilize and encourage students' activity, whereas the primary task of the teacher was to show students how computers works and what can be done with the use of them. However, time has shown that computer manufacturers every year compete in developing constantly innovating improvements. At present, computer is the most important unit of information technology. Its presence is visible at every step (Noga, 2004, Pytel, 2006, Sałata, Ubysz, 2000, Sałata, 2000, Vargová, 2005).

Today, science teacher is facing a challenge: during their classes they have to take into account the varied extracurricular students' interests, try not to bore the more advanced students, give a chance to learn new skills to those who are less interested in computer science or deprived of access to a computer outside the school. In this process it is necessary to use a variety of teaching methods that specifically will mobilize students to active participation in the classes. Particularly noteworthy are the following activating methods:

- project method,

- debate,

- decision tree,

- puzzle.

\section{Planning the educational process with project method}

The author of the classical definition and description of project method was W.H. Kilpatrick (Kilpatrick, 1918), a student and associate of J. Dewey. Theoretical basis of the method were formed by C.A. McMurry and F.M. McMurry (McMurry \& McMurry, 1987), J.A. Stevenson (Stevenson, 1921) and H.B. Alberty (1927).

The project method has become a perfect medium of new pedagogical experiences that have contributed to the fact that teachers gave up the classlesson system for projects combining the various contents. Such actions should lead to children's independent work in the field of their interests.

Due to the type of activity, projects are divided into two major groups:

focused on cognitive activity focused on practical activity 
On the other hand due to the range of educational material projects can be divided into three types:

\begin{tabular}{|l|l|l|}
\hline lessons projects & module projects & interdisciplinary projects \\
\hline
\end{tabular}

Due to form of students work two types of projects can be distinguished:

\begin{tabular}{|l|l|}
\hline uniform & varied
\end{tabular}

The main phases of work with the project method are presented in the Tab. 1.

Table 1 Phases of work with the project method

\begin{tabular}{|l|l|}
\hline Preparatory phase & Proper phase \\
\hline$-\quad$ Planning the project by the teacher. & - Selecting and formulating the subject \\
$-\quad$ Initiating project. & and the objective of the project. \\
& - Analysing the project's conditions. \\
& - Planning and organizing activities. \\
& - Preparing for implementation, writing \\
& - the contract. \\
& - Implementation of the project. \\
& - Pevelopment of the project. \\
& - Evaluation. \\
\hline
\end{tabular}

\section{Project method as a medium for new didactic and pedagogical experiences}

Teachers using the project method noticed that it is the perfect method for combining different contents and forms of students' activity. Working with the project method enables children to acquire learning skills, develop their knowledge, learn, communicate, negotiate, control their emotions, resolve conflicts, take responsibility for their own work and the work of their colleagues and teams.

\section{Project method as a factor of students' personality training}

Projects concern the development of students' organizational and technical skills, imagination, technical thinking, commitment to work, accuracy, precision, self-discipline, positive attitude towards the work of other participants, waking up the need to be creative, confidence in their own abilities of defining and forming an efficient problem-solving solutions, harmonious cooperation with other participants. 


\section{Project method as a development of skills}

This method enables effective development of not only students' knowledge but also their skills. There are two types of skills: universal and specific. Universal skills are related to the implementation of individual phases of the work on the project. Specific skills depend on the type of project. Using the project method largely depends on the situation.

\section{Project method as a micro school}

In the time of education reform, a wide group of teachers are reaching for new teaching methods. The project method is to some extent competing with traditional teaching methods. Many teachers determines the project method as a micro school. It's a fairly wide concept, often associated with the school institution and not the way to teach children.

However, nowadays the lack of appropriate teaching methods makes many students seek science knowledge in new mass media. That is why it is so important to adapt teaching methods to changing conditions of education.

\section{Project method as a factor of developing students' interest}

Nowadays, teachers are facing a very important task of improvement of traditional teaching methods and exploring new, more creative ones, that will have more children and young people interested in surrounding world. Based on the literature analysis, we can conclude that the fundamental elements shaping the interests of each individual are:

\begin{tabular}{|l|l|}
\hline experiencing anxiety to novelties & experiencing success with the taken action \\
\hline making independent decision to learn & experience of failures of the taken action \\
\hline
\end{tabular}

The primary objective of the shaping interests is to reinforce the effects of the student's work through the appreciation of their activities. The presentation of the project is the perfect situation to do it. Properly prepared and original presentation evokes admiration, appreciation and acceptance.

\section{Project method as educational factor}

The independence of decision making is one of the main features of the project method. This method enables teachers to create situations that allows students to develop certain values. Work on the project is well organized which has a positive effect on the creative process, making decisions and taking responsibility for them. This process entails greater students' involvement in work and shaping a positive attitude towards it. Educational factor and its various forms depends on the type of the project:

- projects of a practical nature, like „to do”, 
- projects for the local community, a ,social service”,

- local action projects,

- projects carried out collectively.

\section{Research}

The subject of the study are the opinions of students and teachers on the use of the project method in technology and IT classes. The purpose of the study is to understand the awareness of sixth grade of primary school pupils and the first grade of high school students and their teachers about the methodology of the classes, with particular regard to the importance of the project method.

The survey conducted in October 2015 included 24 pupils of sixth grade of primary school (aged 12-13 years old), 52 first grade of junior high school students (aged 13-14 years old), 2 teachers of technology education and 3 teachers of IT classes. The study was conducted in the Primary School No. 2 in Gruszów and in the Public School No. 2 in Gruszów.

Analysis of the results showed that in pupils' opinions there are many factors affecting their interests in technology and IT classes, but the most important are practical exercises (35\%). Teachers can engage pupils in lessons by answering their questions ( $21 \%)$, using the net (15\%), combining theory with practice $(7 \%)$ and discussing interesting topics $(7 \%) .15 \%$ of surveyed pupils stated that nothing can interest them in technology and it classes. All of the listed factors are specific to the project method. The results are presented in the Fig 1.

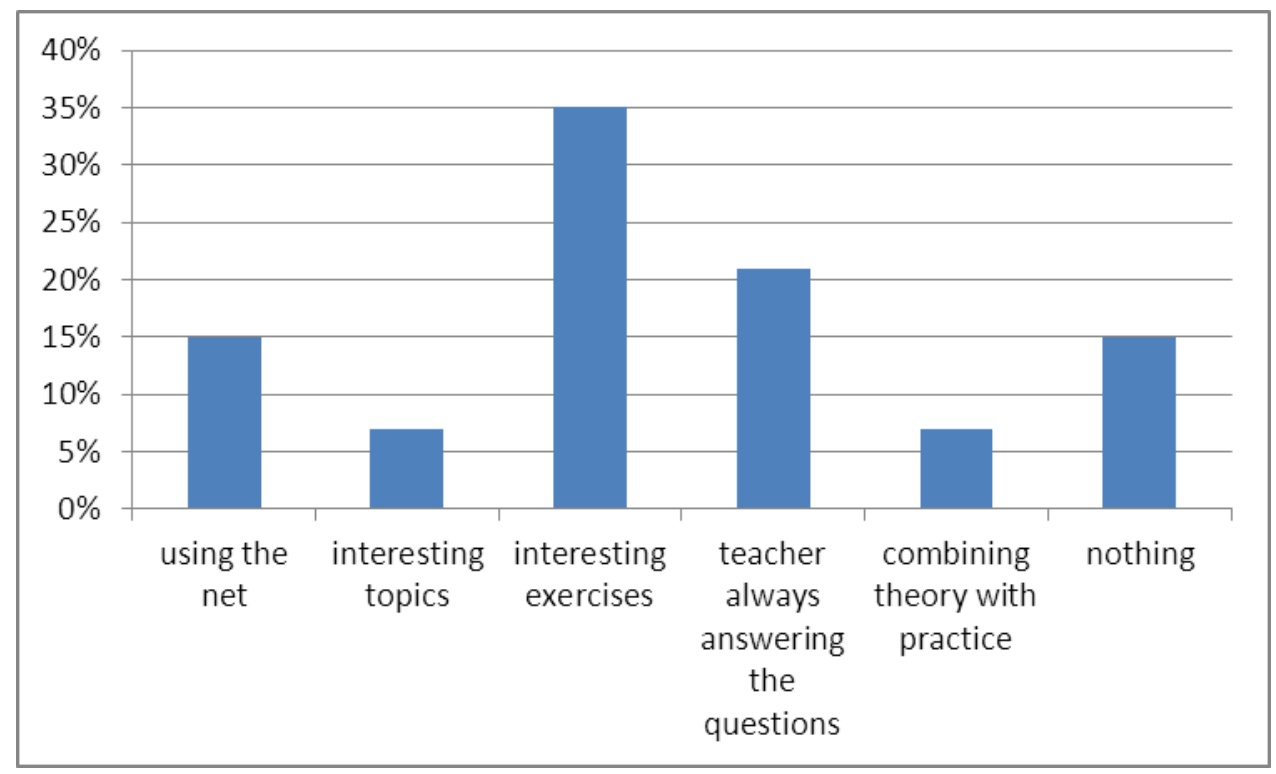

Fig.1 The most important elements affecting the VI grade pupils' interest of technology and IT classes 
The results showed that most of the surveyed VI grade pupils $(85 \%)$ are interested in practical classes, so important in working with the project method. (Fig. 2).

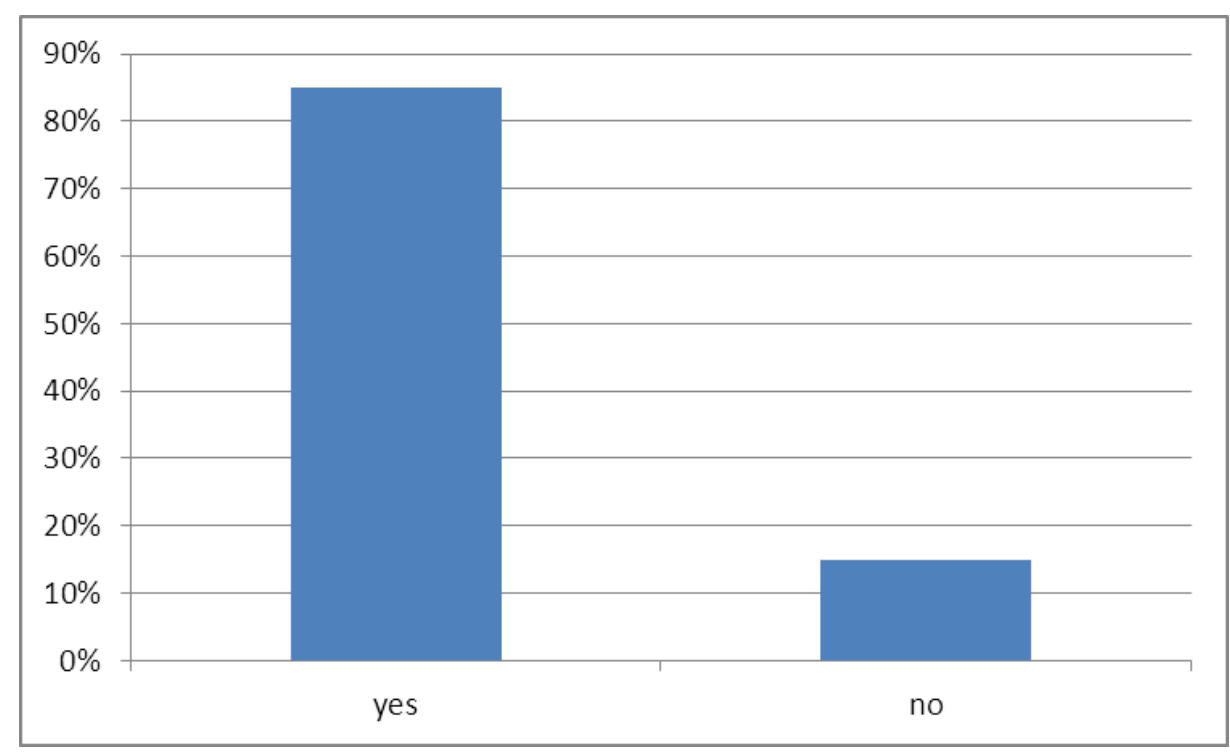

Fig. 2 Percentage of VI grade pupils interested in practical classes

First grade of junior high school students were asked about modifications that are likely to increase their interest in technology and IT classes (Fig. 3). The alarming fact is that the most of the students $(73 \%)$ could not give a single suggestion. However, $16 \%$ of surveyed students stated that increasing the number of practical exercises could be helpful. For $11 \%$ of students fair assessment is the most important.

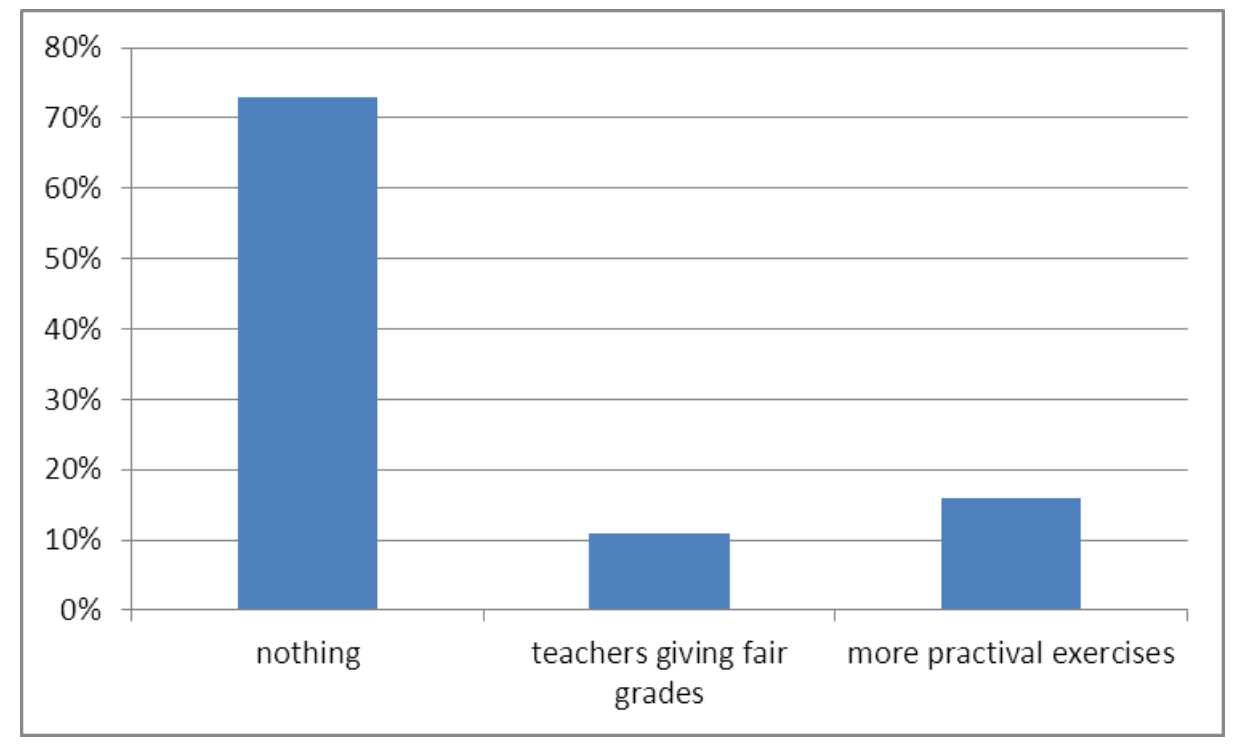

Fig. 3 Preferred modifications in technology and IT classes in junior high school students' opinions 
All of the surveyed teachers declare the use of the project method on their lessons (Fig. 4). $20 \%$ of them use the project method very often, $80 \%$ sometimes. It seems satisfactory, but the analysis of the answers to the next question is disturbing: only $12 \%$ of teachers admit to giving students the large project tasks (Fig. 5).

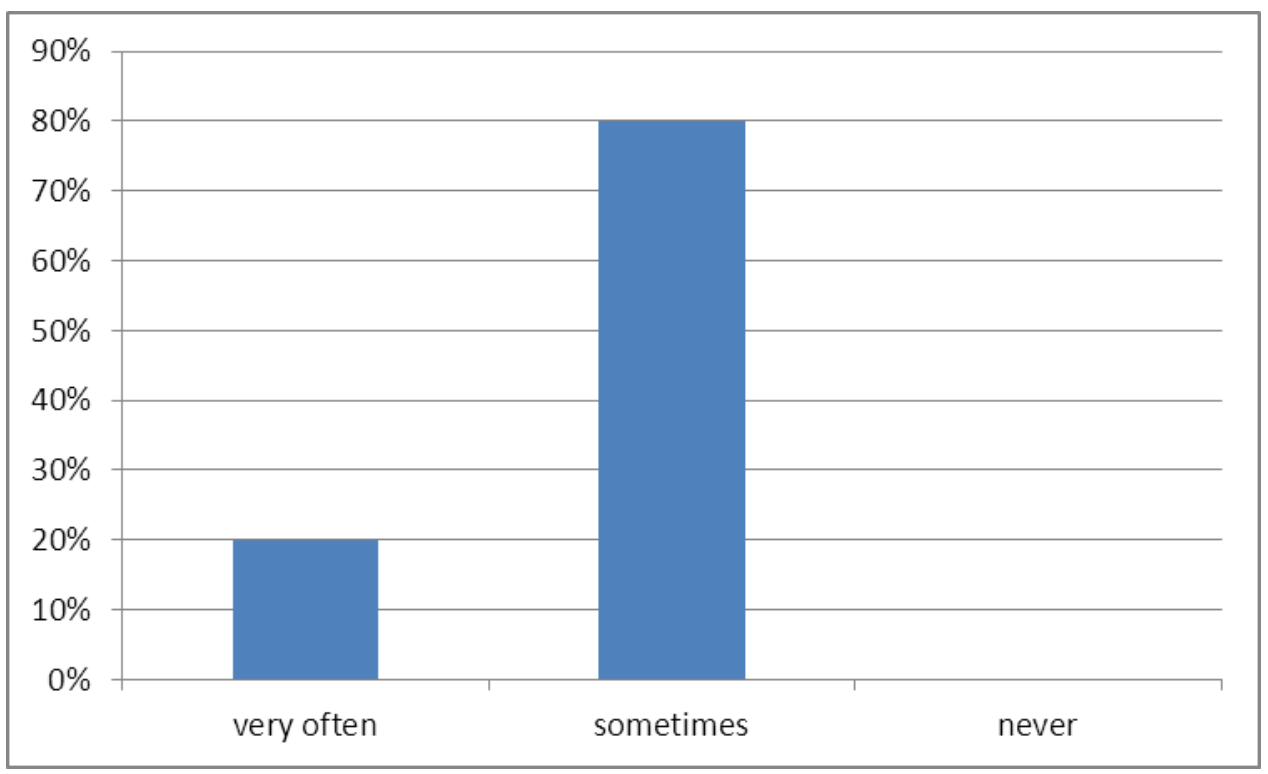

Fig. 4 The frequency of using the project method in technology and IT classes in teachers' opinions

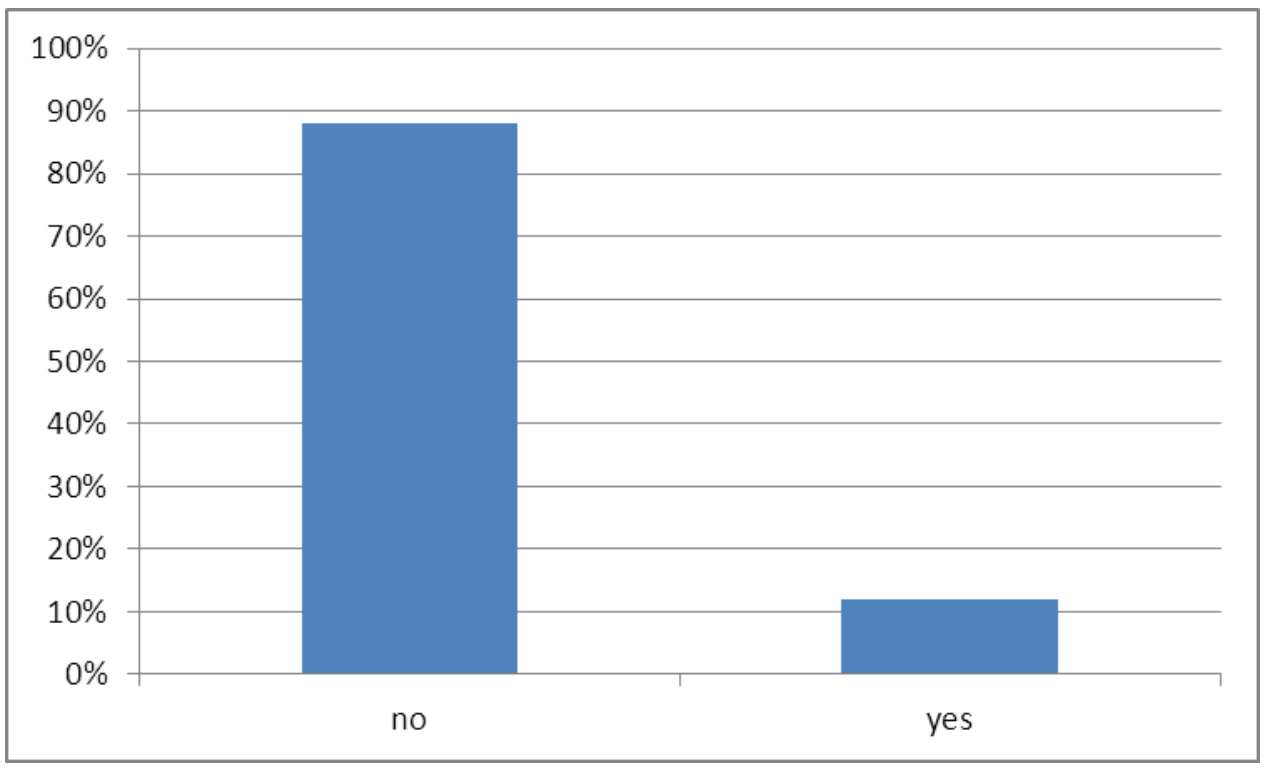

Fig. 5 The percentage of teachers instructing students to large project tasks 


\section{Conclusion}

Both students and teachers are interesting in using the project method in technology and IT classes. All of the surveyed teachers declare using the project method in their classes, although the way it is used may be questionable. Only $12 \%$ of them admit to giving their students large project tasks. Surveyed teachers more often indicate the restrictions of the method.

The possibility of using the project method on technology and IT classes is confirmed by the students' opinions on the factors affecting their interest in the classes. All of the listed factors are specific to the project method (practical exercises, teacher's attitude, combining theory with practice, using different sources of information).

The high percentage (73\%) of surveyed students have no suggestions of how to improve technology and IT classes, which is concerning. $16 \%$ of them would prefer more practical projects.

Surveyed students think that project method has many advantages. The main advantage in their opinions is the possibility of independent solving specific problems. Classes conducted this way, according to respondents are more interesting, more activating and encouraging the creativity in new solutions.

The fact that students are becoming more demanding, can make teachers interest more in other teaching methods. The main task of every teacher who applies the project method to educational process is to interest young people in implementing the specific project. The results of the research show that students are interested in practical methods, also in technology and IT classes.

\section{References}

Alberty, H. B. (1927). A study of the project method in education. Columbus: Ohio State University Press.

Kilpatrick, W. H. (1918). The project method. The use of the purposeful act in the educative process. New York: Techers College. Columbia University.

McMurry, C., \& A., McMurry, F. M. (1897). The method of the recitation. Bloomington: Public School Publishing Company.

Noga, H. (2004). Rola wartości humanistycznych w kształceniu informatycznym. In: Kajdasz-Aouil, M., Michalski, A., Podoska-Filipowicz, E. (Eds.) (2005). Edukacja techniczna i informatyczna: kreowanie nowoczesnego modelu ksztatcenia, 267-273. Bydgoszcz: Wydawnictwo Akademii Bydgoskiej im. Kazimierza Wielkiego.

Mastalerz, E. (2006). Edukacja informatyczna w dobie narastającego uzależnienia od komputera. In: Mastalerz, E. (Ed.) Cyberuzależnieni@: przeciwdziałanie uzależnieniom od komputera i Internetu (pp. 22-31). Kraków: Niezależne Zrzeszenie Studentów Akademii Pedagogicznej.

Petlák, E. (1997). V̌̌eobecná didaktika. Bratysława: IRIS. 
Prauzner, T., \& Ptak, P. (2014). Analiza parametrów pracy wybranych czujników pola magnetycznego. Przeglą Elektrotechniczny, 12/2014, 273-276.

Pytel, K. (2006). Wpływ Internetu na rozwój i zachowanie dzieci i młodzieży. In: Mastalerz, E. (Ed.) Cyberuzależnieni@: przeciwdziałanie uzależnieniom od komputera i Internetu (pp. 77-83). Kraków: Niezależne Zrzeszenie Studentów Akademii Pedagogicznej.

Pytel, K. (2011). Availability and reliability analysis of large wind turbine systems in chosen localizations in Poland/Analiza dostępności i niezawodności dużej elektrowni wiatrowej w wybranych lokalizacjach w Polsce. Journal of KONBiN, 20 (1), 29-36.

Sałata, E., \& Ubysz, A. (2000). Samoocena pracy nauczyciela jako element jakości nauczania. Pedagogika Pracy, 37/2000, 30-36.

Sałata, E. (2000). Realizacja funkcji dydaktycznej przez młodych nauczycieli. In: Szlosek, F. (Ed.) Kształcenie nauczycieli a reforma systemu edukacji w Polsce, (pp. 114-121). Radom: Wydawnictwo i Zakład Poligrafii Instytutu Technologii Eksploatacji.

Stevenson, J. A. (1921). The project method of teching. New York: The McMillan Company.

Šimonová, I. (2006). ICT implementation into professional English teaching and learning at the FIM. In: Zborník abstrakov z medzinárodnej konferencie $S$ cudzími jazykmi $v$ Európe žit'-pracovat' - študova. Koszyce: Technická univerzita.

Vargová, M. (2005). Inovačné a alternatívne koncepcie vzdelávania v technickej výchove. Dizertačná práca. Nitra: PF UKF.

Vargová, M., \& Depešová, J. (2000). Poznámky k niektorým pojmom technickej terminológie. In: Vplyv technickej výchovy na rozvoj osobnosti žiaka (pp. 107-110). Nitra: PF UKF.

Vargová, M., \& Tomková, V. (2002). Pracovné vyučovanie v súvislosti s prácou s počítačom. In Vplyv technickej výchovy na rozvoj osobnosti žiaka (pp. 167-170). Nitra: PF UKF. 